ened vessels, and may incur the risk of apoplexy; or, on the other hand, starve the patient, or we perpetuate the state of anæmia.

There is an after-train of symptoms arising from loss of blood, consisting of reaction, particularly affecting the heart and brain, which to some extent imitates active disease. There is violent palpitation, acute pain in the head, violent throbbing of the carotids, and intolerance of light and sound. Great care must be taken not to treat such symptoms by local or general blood-letting, as has sometimes happened. A good diet, stimulants, steel and tonics, are required in such cases.

ON THE

\section{PRINCIPLE OF THE SEWERAGE IN LONDON AND OTHER LARGE CITIES.}

BY MARSHALI HALL, M.D., F.R.S., \&.

\section{To the Editor of THE LANCET.}

SiR,-The accompanying Essay will prove to you that I have long devoted attention to the very important subject of this note. I will therefore, without further preface, lay before vour readers what I deem, after all the consideration I have given to it, the true principle of the sewerage of large towns:-

1. In the first place, the present sewers should terminate in one or more ample cloace, arranged along and within the borders of the river, or along any other lowest line;

2. From this cloaca, or these cloacæ, retur'n branch sewers should originate, along which the sewage may be propelled by engine power ;

3. Each of these return sewers should be prolonged to the most convenient spot near one of the principal railways, and then terminate in a reservoir or closed depôt;

4. From this depôt I propose that the sewage be pumped into closed railway waggons, established on offsets from each railway;

5. Along the adjacent railway these waggons may travel, after the departure of the mail-trains, each night, performing a night-service, and conveying the sewage to a distance of 50 , 100 , or 500 miles, into agricultural districts, and finally along branch railways, corresponding with the former, to $a_{0}$ final closed depôt;

6. From this last the sewage may be conveyed to individual fields even, not by the farmer, but by arrangements made by a sewage company, where and when it may be required.

We have only to consider how much food for man and cattle, and how much water, are brought into London or any given city or town, daily, to form an approximate idea of the exact extent of my project, in any instance.

The proceeds will amply pay the interest, and even refund the prime cost. The loss sustained by our fields will be restored, pari passu; the importation of bones and of guano may cease; the pollution of the atmosphere and of the river will be prevented; the threatened nuisance and infection at Plumstead will be avoided.

I am, Sir, your obedient servant,

London, Sept. 1856. Marshall hali.

\section{THE YELLOW FEVER IN BRITISH VESSELS} IN THE WEST INDIES.

\section{To the Elitor of THE LANCET.}

SIR, - I have read, in your journal of the 13th inst, the letter of a late assistant-surgeon, R.N., and your observations thereon, and I most cordially sympathise with the feeling for the preservation of the lives of men serving in her Majesty's ships in the West Indies, by which they were dictated. The letter, however, contains inaccuracies, and it is calculated to convey erroneous impressions of the amount of hospital accommodation and of medical asssistance which is now afforded the sick at Jamaica; and its publication may thus create needless alarm in the minds of persons in this country, who have relatives or friends serving in the West Indian squadron. I therefore request your permission to make the following observations on the subjects discussed in your correspondent's letter.

My connexion with the Jamaica Hospital commenced in 1844 , and from that time to the present, the building (which is certainly the finest and most beautiful of the kind in the West Indies) has been found fully adequate to the comfortable acommodation of all the sick who were sent to it from the squadron. The present permanent medical staff of the hospital, a deputy inspector, staff-surgeon, and two assistant-surgeons, is fully equal to the duties to be performed. The necessity for additional medical assistance has occurred only once within my experience - on the first appearance of cholera in 1550 , when three medical officers were borrowed for a time from the ships then in port. Besides the hospital, the line-of-battle ship, the Imaum, is stationary at Port Royal, as a receiving and convalescent ship, which might be used as a supplementary hospital. There are also lofts in the Naval Yard, where the crews of the Termagant and Malacca were berthed, with the best results, while the ships were undergoing purification. The Imaum bears on her books two medical officers, who may be said to have little or no duties to perform on board, as the hospital receives their sick, and they are therefore both disposable for service in a ship in port when required.

I learn, from a communication I have just received from Jamaica, that when the Atrato sailed from Port Royal on the 27 th ult., there were only twelve men sick in hospital, and that the general health in the ships was "good, as they are free from all epidemic disease." When the state of my health compelled me to return for a short time to England, I left in charge of my duties, Dr. M'Kinlay, the staff-snrgeon, than whom there is not a more efficient officer in the service, and two able and acclimatised assistant-surgeons, Messrs. Murphy and Wallace. As to your correspondents remarks on the treatment of the two gentlemen last mentioned, I have only to say that I received an intimation from the Director-general so far back as May last, that Mr. Murphy, the senior, would be promoted when he returned to England, and qualified; and it is entirely by his own choice that he remains in the Jamaica Hospital. Mr. Wallace refused an acting appointment as surgeon of the Daring, last month, after the death of Mr. Edwards. I have reason to know that the services of both the assistantsurgeons are duly appreciated, and that they will be rewarded. Your correspondent also suggests that the sick from mail packets and English merchant ships should be received into the Naval Hospital; he is evidently not aware that they are now admitted, as well as the sick from foreign vessels of war and merchantmen. He is also in error, when, trusting to the Navy List, he states that the Hermes was left without an assistant, as Mr. Humphries joined her from the Boscawen before Mr. Ward was taken ill.

I may state that whenever epidemic disease appears in a ship at Jamaica, a medical inspection takes place, and a report is made, with recommendations as to the best mode of checking it. In the great majority of instances, as was lately the case in the Termagant and Mralucca, no appreciable source of disease is detected, and the most efficacious, if not the only mode of arresting the progress of epidemic yellow fever, is the removal of the ship in which it breaks out to the northern part of the station, a step which was successfully adopted in the recent cases at Jamaica.

I have the honour to be, \&c.,

Oxford-terrace Hyde-park.

J. WATSON Sept. 15 th, 1856 . Deputy-inspector of the Jamaiea
Hospital.

Health of London during the Week ending Saturday, September 20.-In the week that ended on Saturday, the deaths registered in London were 1064. The rate of mortality that now rules is very near the average in the corresponding weeks of ten years $1846-55$, if this average is reduced by eliminating deaths caused by cholera in the epidemic years 1849 and 1854 . In the last three weeks the total numbers returned have been 1100,1087 , and 1064 ; and the decrease which they exhibit nearly agrees with the decrease of deaths from diarrhœa, returned in the same periods, which were 124,116 , and 95 . Besides these 95 deaths of last week, there were three cases of cholera amongst infants, and 11 of dysentery amongst persons of various ages. Typhus and common fever were fatal in 45 cases; scarlatina in 39 . Neither of these complaints produces more than its ordinary proportion of mortality; they appear indeed to be rather less fatal than usual ; but the greatest number of deaths from both of them occurred in the Eastern division of London. A man, aged $\mathbf{4 2}$ years, died in Basinghall-street of scarlatina maligna after an illness of 5 days. Only 4 deaths occurred from small-pox, all amongst children; and 23 from measles; 2 from ague ; 1 from scurvy. One person died of intemperance; one of privation 10 children from want of breastmilk. A house painter, aged 46 years, died from "lead-poisnning." Four nonagenarians appear in the registration of the week. 